\title{
Cultural Heritage and Methodological Approaches-An Analysis through Initial Training of History Teachers (Spain-England)
}

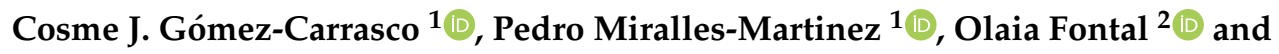 \\ Alex Ibañez-Etxeberria ${ }^{3, * \text { (D) }}$ \\ 1 Departament of Mathematics and Social Sciences Education, University of Murcia, 30003 Murcia, Spain; \\ cjgomez@um.es (C.J.G.-C.); pedromir@um.es (P.M.-M.) \\ 2 Department of Didactics of Musical, Plastic and Corporal Expression, University of Valladolid, \\ 47002 Valladolid, Spain; olaia.fontal@uva.es \\ 3 Departament of Social Sciences Education, Universiy of the Basque Country (UPV-EHU), \\ 20018 San Sebastian, Spain \\ * Correspondence: alex.ibanez@ehu.eus; Tel.: +34-943-017-068
}

Received: 2 December 2019; Accepted: 23 January 2020; Published: 27 January 2020

\begin{abstract}
Research on heritage education has progressed remarkably and a large number of studies point to a greater presence of active methodologies and the use of resources and primary sources in the classroom. At this point it seems important to investigate the perceptions and experiences of future history and social science teachers. Thus, this paper studies the value that 506 Spanish and English teachers in initial training place on heritage and its presence in the teaching-learning process of history, as well as their views on the existing connections between methodological perceptions and the use of cultural heritage in the classroom. It is a non-experimental descriptive and quantitative study with data collected through questionnaire. This questionnaire was built ad hoc to analyze the opinions and perceptions of teachers in initial training about history education in Secondary Education. The results show that teachers in initial training value highly or very highly the use of cultural heritage in Secondary Education to promote active methodologies, the critical teaching of history, and the development of historical skills. Teachers in training in Spain value more highly the use of heritage than English teachers. While English teachers in training value more highly the resolution of problems through historical documentary sources, Spanish teachers rate the emotional and motivational aspects higher.
\end{abstract}

Keywords: cultural heritage; heritage education; history education; teacher education; methodological approaches; active methodologies

\section{Introduction}

\subsection{History Education from the Perspective of Heritage Edcucation: Towards the Development of Civic} Competence in Teacher Training

In the last decade many papers have studied in depth the links and reciprocities between heritage education, historical education, the construction of a critical citizenship, and a non-exclusive identity education. Some international studies are examples of this integration effort [1-6]. In Spain, in particular, scientific production derived from research in heritage education has also increased, coinciding with the creation of two powerful heritage management instruments by the Central Administration: the National Education and Heritage Plan from the Ministry of Culture [7] and the Spanish Heritage Education Observatory from the Ministry of Universities [8]. In this sense, Fontal and Ibañez-Etxeberria [9] (2017) 
offer a bibliometric study of the scientific production on heritage education over the last ten years and show how the evaluation of programs accounts for the greatest scientific production in the last 6 years. Some of these studies emphasize evaluation based on standards [10-14], others are oriented towards the evaluation of implementations, both in formal and non-formal spheres, with special emphasis on the use of Information and Communication Technology (ICT) $[15,16]$. Other research has focused on qualitative assessments $[17,18]$ and on the analysis of educational resources $[19,20]$ or the evaluation of learning [21]. Elsewhere, the design and validation of measurement instruments from psychometric rigor, such as the Q-Edutage scale, aimed at evaluating the quality of heritage education programs [22], and other solvent construction instruments for the evaluation of programs and learning [23-25] have begun to develop a hitherto deficient area. Also, coinciding with the European Commission's demand, studies on accessibility and social inclusion through heritage [26,27] have begun to have an impact, seeking learning for all people, in all contexts and moments of life and with special attention to people with functional diversity [28-30].

All this research contributes to establishing a systemic, participatory, interactive, complex, and sociocritical vision of heritage and heritage education [31,32], and provides a foundation for the relationship between heritage, citizenship, and the construction of identity [33].

Fortunately, classroom experiences with objects and material remains from the past are increasingly frequent, elaborate, and successful [34-37]. Philips [38] makes a very positive assessment of the articles published in this issue and highlights the methodological changes that have taken place thanks to the incorporation of these work proposals.

The links between using heritage for the development of historical thinking are significant [39]. Seixas and Morton [40] identified six concepts of historical thinking: historical relevance; historical sources and evidence; causes and consequences; changes and permanences; historical perspective; and historical dimension. Heritage is based on historical sources and material vestiges, and its application in the classroom leads to critical analysis and interpretation of sources and the ability to extract evidence from them, which allows us to construct a historical argument of our own. These second-order concepts have been at the center of an international debate on the learning of history based on the skills of the historian [41-45]. This approach focuses on understanding history as a method for learning to think and reflect with and from history. In this context, the research in the background of the students (associated with more traditional or more active models) becomes important to design formative programs that improve teaching practices. Some studies associate heritage elements, identity conflict, and historians' skills for historical argumentation [46] with the development of civic competence [47].

The concept of historical thinking has gained in strength over the past two decades as an alternative to descriptive and uncritical historical discourse. Éthiers, Demers, and Lefrançois [48], after a review of the French-language bibliography, stress the methodical character of historical thinking. These authors insist that this concept refers to the capacity to construct knowledge of the past, and that it integrates both the temporal perspective and a critical interpretation [46]. The sources and method of the historian, therefore, form an inseparable part of this definition of historical thinking, although the results show the great difficulties students have in generating interpretations that combine sources with divergent information [49].

Ashby [50] pointed out several issues needed to understand working with sources in the classroom. First, the historical source is a concept, not a skill or a competence. Second, it is necessary to distinguish between historical sources and historical evidence. While the concept of historical source refers to all material and immaterial remains of the past, the concept of historical evidence is related with the abilities to collect information of historical sources [51]. It is necessary to work with students with primary sources, objects, and artifacts of the past, to develop competencies in the interpretation of history. This requires other teaching practices more linked to active methodologies in the field of history education, which represent an important conceptual change in rigid educational systems such as the Spanish case. 
For more than a decade, academic research has insisted on a change in teaching practices on history education. In this context of change towards a new scenario where activities promoted from an active methodology are more valuable, it becomes important to research in Spain about teaching practices and beliefs of teachers in training. It is also relevant to check if this change tends towards generalization, and if it is comparable to other systems such as the English case, with a very different conception of history education, both from the methodological and epistemological scope.

The area of research in this work has been teacher training, since we consider that the background of the teacher in initial training accumulates the teaching models received in secondary education and the Faculty of History. Therefore it represents a broad, although partial, vision of the teaching practice, while reflecting through their own convictions, the incidence of different traditions and the possible future of these. In recent decades, initial and continued teacher training has become a central issue [52]. International studies insist on the need to renew teacher training programs in order to improve teaching-learning processes in compulsory education [53,54]. Many authors state that more comparative research is needed to transfer these findings to classroom teaching practice [55].

Within the lines of research on teacher training, the analysis of the knowledge and conceptions of teachers in training has taken on a fundamental role in orienting initial training programs $[56,57]$. Noteworthy here is the research that seeks to calibrate the different types of professional knowledge of the teacher, emphasizing the mastery of the habitual tasks of the classroom $[58,59]$.

Despite the continuous increase in studies on teacher training in history education, there is not much research from a global perspective and with solid empirical support [60]. One exception in recent years, from the Netherlands, is the work of the group led by Van Boxtel, which has advanced in more powerful empirical analyses, both at the level of methodological complexity and in conceptual depth [61], leading to the validation of questionnaires and other instruments for collecting information and observation scales having a greater impact on the research area [62-64].

\subsection{Research Question and Aims}

The research question addressed in this paper is the following: "what is the relationship between methodological conceptions of history and opinions on the use of cultural heritage in the Secondary Education classroom?" With this research problem we propose two specific objectives:

SO1: To compare the assessment of history teachers in initial training in Spain and England on heritage and its role in the teaching-learning process of history.

SO2: To define the main components needed to analyze the existing connections between methodological perceptions and the use of cultural heritage in the teaching-learning processes in history teachers in training.

\section{Method}

\subsection{Participants}

The context in which this research took place is the professional postgraduate degree that provides graduates with the required qualification to become Secondary Education teachers of History both in Spain and in England. 506 teachers-in-training were recruited, all of whom were enrolled in either Spain's Master's degree in secondary education, History and Geography specialty (344), or England's Postgraduate Certificate in Education courses or Teach First programs (162) by the end of academic year 2015-2016. 22 universities joined the study, 13 from Spain and 9 from England. Demographic characteristics of the sample in Tables 1-3. 
Table 1. Participants who answered the questionnaire. Distribution by countries.

\begin{tabular}{ccc}
\hline & $\mathbf{N}$ & $\mathbf{\%}$ \\
\hline Spain & 344 & 67.9 \\
England & 162 & 32.1 \\
Total & 506 & 100 \\
\hline
\end{tabular}

Table 2. Distribution by age and country of the participants who answered the questionnaire.

\begin{tabular}{ccccc}
\hline Age & Frequency Spain & \% Spain & Frequency England & \% England \\
\hline $20-25$ & 214 & 62.2 & 98 & 60.5 \\
$26-30$ & 68 & 19.8 & 33 & 20.4 \\
$>30$ & 34 & 9.9 & 14 & 8.7 \\
NC & 28 & 8.1 & 17 & 10.4 \\
Total & 344 & 100 & 162 & 100 \\
\hline
\end{tabular}

Table 3. Distribution by sex of the participants who answered the questionnaire in Spain and England.

\begin{tabular}{ccccc}
\hline Sex & Frequency Spain & \% Spain & Frequency England & \% England \\
\hline Male & 187 & 5.4 & 61 & 37.7 \\
Female & 139 & 40.4 & 100 & 61.7 \\
Total & 326 & 94.8 & 161 & 99.4 \\
No answer & 18 & 5.2 & 1 & 0.6 \\
Total & 344 & 100 & 162 & 100 \\
\hline
\end{tabular}

The choice of these two countries is due to their different traditions in History education-in the case of England focused on the development of historical skills, in contrast with Spain's emphasis on conceptual contents and transversal competencies.

\subsection{Design of the Research}

A non-experimental quantitative design was used, with collection of information through a questionnaire with a Likert scale (1-5). This type of design was chosen because it is capable of responding to problems both in descriptive terms and in relation to variables, when the information is collected systematically, thus guaranteeing the rigor of the data obtained [65]. Survey designs are very common in the field of education as they are applicable to multiple problems and allow information to be collected on a large number of variables [66].

\subsection{Data Collection Tool}

The data used in this work form part of a questionnaire entitled "Opinion and perception of teachers in initial training on the learning of history and the assessment of historical competences". The questionnaire was validated by four experts, three from the teaching-learning area of the social sciences from three universities, who possess extensive experience in Secondary Education, and a fourth, an expert in Educational Research methods. The questionnaire completed by the validators was designed with a Likert scale of four values (1 lowest- 4 highest). This questionnaire was structured around the relevance and clarity of each of the items comprising the tool. Only items that exceeded 3 on average in both categories (relevance and clarity) were included. In addition, all the issues indicated were modified qualitatively.

The first part of the questionnaire collects data on the participants' university of origin, sex, age, and previous training. The second part is made up of three thematic blocks. The first block, entitled "Opinion and perception on evaluation and their role in the teaching and learning process", contains 12 statements on the role of evaluation which participants scored from 1 (totally disagree) to 5 (totally 
agree). The questionnaire items related to evaluation procedures and activities were constructed taking into account teaching practices related to traditional and innovative profiles.

The second block, entitled "Opinion and perception about formative history, methods, sources, and teaching resources," contains 15 statements that participants scored from 1 (strongly disagree) to 5 (strongly agree), and 24 methods, techniques, and teaching resources for teaching history that participants scored from 1 (least relevant) to 5 (most relevant). The items focused on obtaining information on respondents' perceptions of methodological and epistemological perceptions of history and its function as an educational subject. In the statements that measure the perceptions of teachers in training about history as academic knowledge and as a formative subject, the objective, subjective or critical nature of historical knowledge is valued. Here we adapt some of the items proposed by Maggioni, VanSledright, and Alexander [67] and VanSledright and Reddy [68] from their BHQ (Beliefs History Questionnaire), following the recommendations of works such as Stoel, Logtenbergb, Wansinkc, Huijgend, Van Boxtel, and Van Drie [61] or Stoel, Van Drie, and Van Boxtel [69]. Regarding Teaching methods and techniques, works such as Gómez, Miralles, and Chapman [70] or Gómez, Rodríguez, and Mirete [71] have been taken into account.

The third block, entitled "Opinion and perception on the assessment of historical competences in Secondary Education: use of sources, causal reasoning, and historical empathy", contains 9 statements that participants scored from 1 (strongly disagree) to 5 (strongly agree), and 8 historical competence assessment activities that participants scored from 1 (least relevant) to 5 (most relevant). The 9 statements in the third block of the questionnaire were based mainly on three of the main concepts of historical thinking: causal explanation; sources and evidence; and empathy or historical perspective.

In order to achieve the objective set out in this work, the information from block II "Opinion and perception of history as a formative subject, methods, sources, and teaching resources" (Supplementary Material) has been used.

After the validation of the questionnaire by the experts, the questionnaire was translated into English and submitted for validation by the ethics committee of the Institute of Education of University College of London for its implementation in English centers. The ethics committee of the Institute of Education resolved positively and the questionnaire could now be distributed in Spanish and English centers.

In Spain we contacted coordinators and teachers of the Máster de Formación del Profesorado de la especialidad de Geografía e Historia. Paper-based questionnaires were sent to the universities which agreed to take part: Murcia, Alicante, Valencia, Barcelona, La Rioja, Zaragoza, Oviedo, Santander, Valladolid, Burgos, Autónoma de Madrid, Málaga, and Jaén. In England, following contacts with the relevant teachers in May, some universities chose paper-based questionnaires, while others opted to receive the electronic link and to pass it on to their students. The paper-based version was used by the IoE-UCL, University of Exeter, and the University of Edge Hill, while trainee teachers at Metropolitan Manchester University, University of York, University of Leeds, East-Anglia University, University of Birmingham, and Christ Church University of Cantebury completed the questionnaires online. Data were collected in May (Spain) and June (England) 2016.

\subsection{Procedure and Data Analysis}

The data were coded in the statistical program XLSTAT v.2019.3.2 in three different files: one for each country and one with all the data together. This has allowed us to perform the analysis separately as well as a comparative study to perform country hypothesis tests.

Before proceeding with the data analysis, the degree of reliability and validity of the construct was estimated. To analyze the reliability of the questionnaire, the internal consistency method based on Cronbach's Alfa was used to estimate the reliability of a measuring instrument made up of a set of items, of the Likert scale type, which we expected will measure the same theoretical dimension (the same construct). This validation procedure has also been used by other historical education works [72]. The criterion established and indicated by various authors is that a Cronbach Alpha value, between 
0.70 and 0.90 , indicates a good internal consistency [73,74]. In the case of block II of the questionnaire, adequate results were obtained. The reliability analysis obtained a Cronbach Alpha equal to (0.821) for Spain and (0.825) for England, indicating a high internal consistency.

The validity of the construct and the viability of a subsequent factorial analysis were also checked. For this purpose, the correlation matrix was analyzed and Barlett's sphericity test and a Main Components Analysis (MCA) were carried out, differentiating by country. The exploratory MCA is one of the most frequently applied techniques in studies related to the development and validation of questionnaires. The technique is appropriate if the objective is to identify the number and composition of components needed to summarize the scores observed in a large set of observed variables. The technique explains the maximum percentage of observed variance in each item from a smaller number of components summarizing that information [75].

With the analysis of the correlation matrix, we searched for variables that did not correlate well with any other, that is, with all correlation coefficients less than 3; and variables that correlated too well with others, that is, variables that have some correlation coefficient greater than 9 . The former should be eliminated from the analysis, and the latter we could keep, but bearing in mind that they may cause multicollinearity problems. No variable with these characteristics was found.

The Bartlett sphericity test and the diagonal of the matrix of anti-image correlations were calculated before the exploratory MCA was performed. In the Spanish case, the Barlett's sphericity test was significant $(X 2 \mathrm{gl} .630=2961.48 ; p<0.001)$, which indicates that the matrix is suitable to be factored. With these data, we proceeded to carry out the exploratory MCA obtaining eleven components that explain $58.48 \%$ of the total variance. In the case of questionnaires answered by teachers in training in England, the Barlett's sphericity test was also significant (X2g1.630 $=2,233,232 ; p<0.001)$. With these data, we proceeded to carry out the exploratory MCA, obtaining eleven components that explain $66.77 \%$ of the total variance.

Descriptive data analysis (means and standard deviation), hypothesis tests per country (Student $t$ test), and an exploratory MCA for each of the countries were carried out.

\section{Results}

\subsection{Opinions about the Role of Heritage in the History Class}

Table 4 shows the statistics describing block 2.24 of the questionnaire, in which teachers in training had to assess different resources for their suitability for teaching history in Secondary Education. The item "Museums and other centers of historical interest" is the most valued by teachers in training in Spain, and the second most valued by those in England. In England it is only surpassed by "Primary documentary sources". In Spain, in addition to the item on museums, only primary documentary sources, oral sources, and documentaries with a historical theme scored over 4. In England, only the item of museums and the item of primary documentary sources scored over 4 . The items that scored lowest in Spain are textbooks, comics, and video games, while in England, they are comics, videogames, and historical novels. The other item related to heritage, "Festivals and local traditions of historical content", occupies an intermediate position, with scores of 3.52 in Spain and 3.42 in England. Both items dedicated to heritage showed no statistically significant differences according to the Student $\mathrm{t}$-test (Student t-test $=0.29 ; p>0.05$; Student $\mathrm{t}$-test $=0.26 ; p>0.05$ ).

Figures 1 and 2 reflect the scores given by teachers in training to items associated with museums and other centers of historical interest, and local festivals and traditions with historical content. Both show that the scores of Spanish and English students were very similar. However, it can be seen that the participants from Spanish universities gave a higher percentage of highest scores (5) in both items. This is clearly shown in graph 1 on museums. Almost $50 \%$ of the teachers in training surveyed gave the highest score. There is no doubt that the increase in studies on heritage education in Spain and its links with historical education is one of the causes of this high figure. The close relationship between history, memory, and historical consciousness contributes to the important of heritage in the history class. 
Table 4. Descriptive statistics of the items in block 2.24 of the questionnaire.

\begin{tabular}{|c|c|c|c|c|c|c|}
\hline & $\begin{array}{c}\mathbf{N} \\
\text { Spain }\end{array}$ & $\begin{array}{l}\text { Mean } \\
\text { Spain }\end{array}$ & $\begin{array}{c}\text { SD } \\
\text { Spain }\end{array}$ & $\begin{array}{c}\mathrm{N} \\
\text { England }\end{array}$ & $\begin{array}{c}\text { Mean } \\
\text { England }\end{array}$ & $\begin{array}{c}\text { SD } \\
\text { England }\end{array}$ \\
\hline Textbook & 343 & 2.97 & 1.042 & 162 & 3.39 & 0.986 \\
\hline Internet & 343 & 3.78 & 0.895 & 162 & 3.63 & 0.958 \\
\hline Documentary sources & 343 & 4.23 & 0.815 & 162 & 4.59 & 0.596 \\
\hline Oral sources & 343 & 4.07 & 0.871 & 162 & 3.86 & 0.962 \\
\hline Press & 343 & 3.90 & 0.915 & 162 & 3.62 & 0.892 \\
\hline Teacher's notes & 343 & 3.70 & 0.952 & 162 & 3.53 & 0.879 \\
\hline $\begin{array}{l}\text { Museums and other centers } \\
\text { of historical interest }\end{array}$ & 343 & 4.31 & 0.822 & 162 & 4.23 & 0.733 \\
\hline Cinema & 343 & 3.96 & 0.894 & 162 & 3.42 & 1.014 \\
\hline Documentaries & 343 & 4.01 & 0.836 & 162 & 3.91 & 0.810 \\
\hline Historical novel & 343 & 3.28 & 1.100 & 162 & 3.11 & 1.028 \\
\hline Popular magazines & 343 & 3.36 & 0.935 & 162 & 3.47 & 0.934 \\
\hline Video games & 343 & 3.17 & 1.101 & 162 & 1.93 & 1.016 \\
\hline Comics & 343 & 3.17 & 1.109 & 162 & 2.18 & 1.034 \\
\hline Local and traditional fiestas & 343 & 3.52 & 1.062 & 162 & 3.42 & 1.038 \\
\hline
\end{tabular}

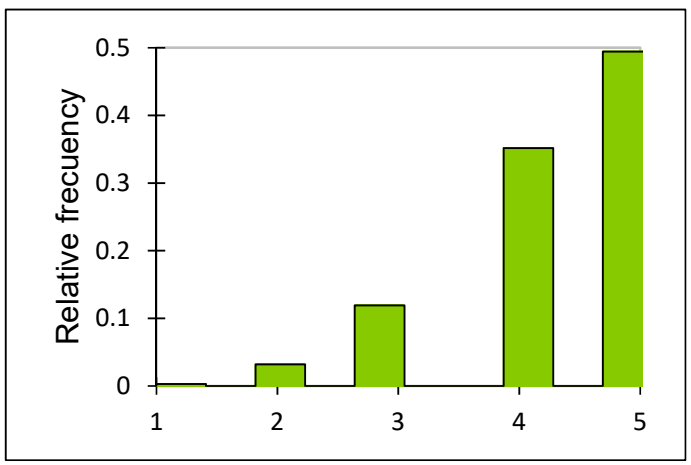

(a)

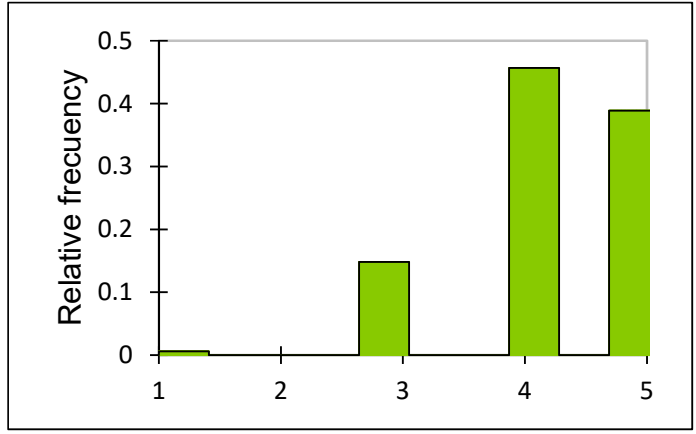

(b)

Figure 1. Rating of item "Museums and other centers of historical interest" as a resource for teaching History: (a) Spain; (b) England. 


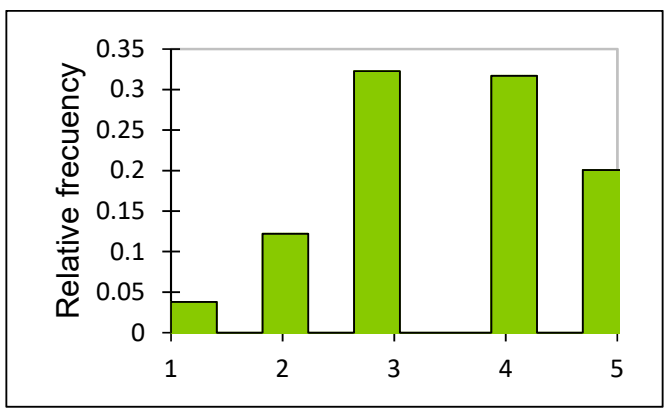

(a)

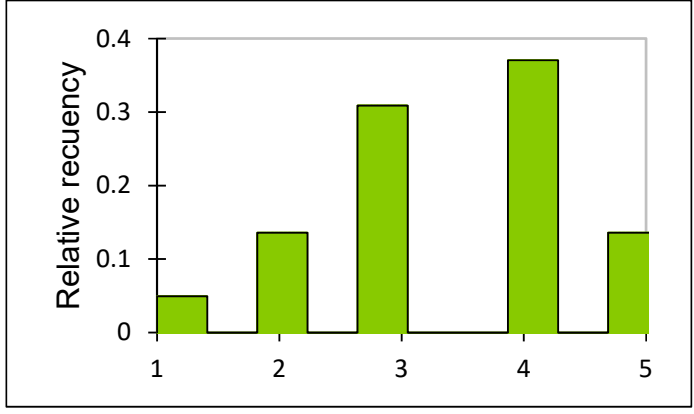

(b)

Figure 2. Rating of item "Local fiestas and traditions of historical content" as a resource for teaching History: (a) Spain; (b) England.

Table 5 shows the descriptive statistics of block 2.25 of items, in which students were asked to rate the most appropriate methods and strategies for teaching history in secondary education. As the table shows, the item "outings to centers of historical interest in the immediate environment" was rated more than 4 in both countries. However, unlike the previous case, it does not score as high as other items. There is a significant statistical difference between the two countries (Student $\mathrm{t}$ test $=0.013 ; p<$ 0.05). Figure 3 offers the frequencies in the responses of teachers in training in Spain and England. Spanish teachers in training again score it high (almost 50\% gave a score of 5), while English students mostly scored it 4. In England only the teacher's explanation and historical simulation strategies scored lower. In Spain, in addition to these two items, the debates on historical topics were also rated lower. While in Spain the most valued item is to use key topics of current interest to connect past and present, in England it is the item on methodological strategies, which is the resolution of historical problems through the search, selection and treatment of information.

Table 5. Descriptive statistics of the items in block 2.25 of the questionnaire.

\begin{tabular}{lcccccc}
\hline & $\begin{array}{c}\text { N } \\
\text { Spain }\end{array}$ & $\begin{array}{c}\text { Mean } \\
\text { Spain }\end{array}$ & $\begin{array}{c}\text { SD } \\
\text { Spain }\end{array}$ & $\begin{array}{c}\text { N } \\
\text { England }\end{array}$ & $\begin{array}{c}\text { Mean } \\
\text { England }\end{array}$ & $\begin{array}{c}\text { SD } \\
\text { England }\end{array}$ \\
\hline Teacher's explanation & 341 & 4.04 & 0.822 & 162 & 3.96 & 0.990 \\
Historical simulation strategies & 341 & 3.89 & 0.895 & 162 & 3.62 & 1.004 \\
Using topics of current interest & 341 & 4.60 & 0.632 & 162 & 4.23 & 0.907 \\
$\begin{array}{l}\text { Problem solving } \\
\text { In-depth studies of historical }\end{array}$ & 341 & 4.34 & 0.732 & 162 & 4.48 & 0.642 \\
cases & 341 & 4.30 & 0.746 & 162 & 4.34 & 0.749 \\
$\begin{array}{l}\text { Outings to centers of historical } \\
\text { interest }\end{array}$ & 341 & 4.28 & 0.798 & 162 & 4.09 & 0.859 \\
Guided debates & 341 & 4.14 & 0.856 & 162 & 4.25 & 0.734 \\
\hline
\end{tabular}




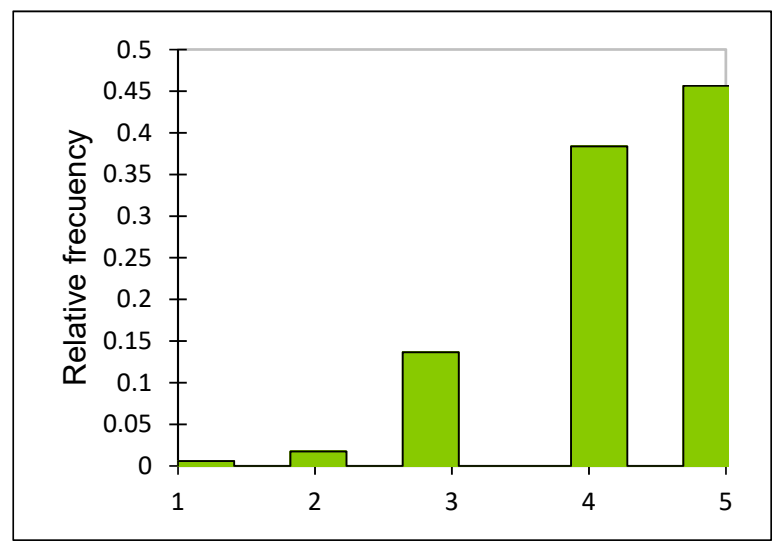

(a)

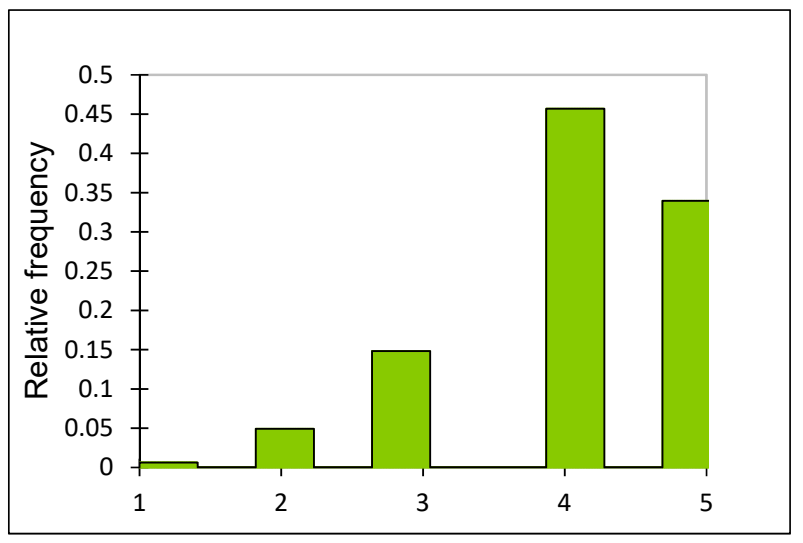

(b)

Figure 3. Scoring of item "Outings to nearby centers of historical interest" as a history teaching resource: (a) Spain; (b) England.

3.2. Definition of the Main Components and the Links of Heritage with Epistemological and Methodological Conceptions

Table 6 includes the matrix of rotated components where it is observed which item saturates in each one of the components (with weights $<0.30$ eliminated from the matrix). We reviewed the reproduced communalities that determine the proportion of variance explained by element or item. Since there are no values close to zero (they range between 0.436 and 0.751 ), we understand that all the items saturate in some of the components. 
Table 6. Rotated components matrix. Dimension 2 "Opinion and perception of history as a formative subject, methods, sources, and teaching resources" (Spain).

\begin{tabular}{|c|c|c|c|c|c|c|c|c|c|c|c|}
\hline & & & & & & Component & & & & & \\
\hline & 1 & 2 & 3 & 4 & 5 & 6 & 7 & 8 & 9 & 10 & 11 \\
\hline History is knowledge of past events & & & & & & & & & 0.618 & & \\
\hline Historical accounts are interpreted subjectively & & & & & & & & & 0.744 & & \\
\hline History consists of a critical study of the past & & & & & & & & & 0.342 & & 0.353 \\
\hline Disagreements among historians are due to the sources & & & & & & & & 0.567 & & & \\
\hline $\begin{array}{l}\text { Curriculum contents: origin and consolidation of the } \\
\text { nation }\end{array}$ & & & & & & 0.681 & & & & & \\
\hline $\begin{array}{l}\text { The historian's methods are fundamental in education } \\
\text { curricula }\end{array}$ & & & & 0.502 & & & & 0.356 & & & \\
\hline Reading skills and memorizing are enough & & & & & & 0.539 & & & & & \\
\hline It is complicated to use enquiry methods & & & & & & & & 0.545 & & & \\
\hline $\begin{array}{l}\text { New technologies help to enhance historical knowledge } \\
\text { through interactivity }\end{array}$ & & & & & & & & & & 0.807 & \\
\hline $\begin{array}{l}\text { New technologies only serve to enhance historical } \\
\text { knowledge with access to working with sources }\end{array}$ & & & & & & & & 0.341 & 0.333 & -0.404 & \\
\hline Understanding the present & & & & & & & & & & & 0.656 \\
\hline Knowing the origin and consolidation of the nation & & & & & 0.358 & 0.735 & & & & & \\
\hline Educating in social and civic values & & & & & 0.554 & & & & & & \\
\hline $\begin{array}{l}\text { Knowing methods for reconstructing and explaining } \\
\text { historical events }\end{array}$ & & & & & 0.619 & & & & & & \\
\hline $\begin{array}{l}\text { Development of educational competences in vocabulary, } \\
\text { chronology, etc. }\end{array}$ & & & & & 0.750 & & & & & & \\
\hline Textbook & & & & & & & 0.705 & & & & \\
\hline Internet & & & & 0.335 & & & 0.311 & -0.312 & & 0.431 & \\
\hline Documentary sources & & & & 0.720 & & & & & & & \\
\hline Oral sources & & & & 0.624 & & & & & & & \\
\hline Press & & 0.303 & & 0.535 & & & & & & & \\
\hline Teachers' notes & & & & & & & 0.481 & & & & \\
\hline Museums and other centers of historical interest & 0.392 & 0.345 & & 0.326 & 0.309 & & & & & & \\
\hline Cinema & & 0.738 & & & & & & & & & \\
\hline Documentaries & & 0.787 & & & & & & & & & \\
\hline Historical novel & & 0.604 & 0.379 & & & & & & & & \\
\hline Popular magazines & & 0.499 & & & & & & & & & 0.325 \\
\hline $\begin{array}{l}\text { Videogames } \\
\text { Vintes }\end{array}$ & & & 0.822 & & & & & & & & \\
\hline Comics & & & 0.807 & & & & & & & & \\
\hline Traditional local fiestas & & & 0.479 & 0.336 & & & & & & & -0.393 \\
\hline Teachers' explanations & & & & & & & 0.734 & & & & \\
\hline History simulation strategies & 0.304 & & & & & & & & & 0.334 & \\
\hline Using key topics of current interest & 0.629 & & & & & & & & & & \\
\hline Problem solving & 0.755 & & & & & & & & & & \\
\hline In-depth studies of historical cases & 0.754 & & & & & & & & & & \\
\hline Outings to centers of historical interest & 0.498 & 0.348 & & & 0.304 & & & & & & \\
\hline Guided debates & 0.528 & & & & & & & & & & \\
\hline
\end{tabular}


The first component extracted, according to the items that saturate it and the topics dealt with by each of them, shows the interactions between the rating of museums as teaching resources of history and all the enquiry strategies (outings to centers of historical interest, debates, problem solving, etc.). In the second component extracted, the relationships between different innovation resources (museums, historical cinema, documentaries, historical novels, and popular magazines) can be verified with the methodological strategy "outings to centers of historical interest". In the third component extracted, the following resources are saturated with positive values: historical novel, video games, comics, festivals, and local traditions. The fourth component shows the interactions between the statement that it is necessary to incorporate the historian's method into the classroom with the evaluation of the following resources: documentary and oral sources, press, and museums. In the fifth component extracted, the relationship between the items that indicate that the purpose of teaching history is to train in social and civic values, to know the methods of reconstruction of the past, and to be trained in educational competences, with the rating of the museum as a resource and outings to centers of historical interest as a methodological strategy can be verified.

The sixth component extracted interrelates traditional assertions about the teaching of history (that content should be based on nation-building milestones and that simple reading skills serve to interpret historical sources), with the assessment that the purpose of history is to know the origin of the nation, a tendency towards positive appreciation of textbooks, and teachers' notes as teaching resources. In the seventh component extracted there is a saturation with positive loads between the assessment of the textbook as a resource, the use of the Internet, the teachers' notes, and an assessment of the methodological strategy of explanation of the teacher. These items saturate negatively with the consideration of history as a critical view of the past. The eighth component extracted shows the interactions between the assertion that simple reading skills serve to interpret sources and the item indicating the difficulty of incorporating inquiry methods into the classroom. In this component there is a negative charge with the valuation of the Internet as a resource. In the ninth component extracted the interrelationships between the item that states that history is simply knowledge of the past, the item that states that the discrepancy between historical interpretations is due to the historian's subjectivity, and that the Internet is only useful when it allows access to primary sources. The tenth component extracted shows a saturation with positive loads of the items in favor of the use of the Internet for the teaching of history with the item that values positively the methodological strategy of history simulation. These elements have a negative saturation with the item indicating that the Internet is only useful when it allows access to primary sources. Finally, the eleventh component extracted shows the interactions between the item stating that history is a critical investigation of the past, the assessment that the purpose of history is to understand the present, and the rating of popular magazines and local fiestas and traditions as useful resources for teaching history.

Table 7 shows the rotated components matrix for the trainee teachers in England, where it is observed which item is saturated in each of the components (with weights $<0.30$ eliminated from the matrix). We reviewed the reproduced communalities that determine the proportion of variance explained by element or item. Since there are no values close to zero (they range from 0.530 to 0.769 ), we understand that all the items saturate in some of the components. 
Table 7. Rotated components matrix. Dimension 2 “Opinion and perception of History as a formative subject, methods, sources, and teaching resources” (England).

\begin{tabular}{|c|c|c|c|c|c|c|c|c|c|c|c|}
\hline & & & & & & Component & & & & & \\
\hline & 1 & 2 & 3 & 4 & 5 & 6 & 7 & 8 & 9 & 10 & 11 \\
\hline History is the knowledge of past events & & & & & & & & & & & 0.762 \\
\hline Historical accounts are interpreted subjectively & & & & -0.541 & 0.367 & & & & & & 0.330 \\
\hline History is the critical study of the past & & & & & & & 0.759 & & & & \\
\hline Disagreements among historians are due to the sources & & & & & & 0.810 & & & & & \\
\hline $\begin{array}{l}\text { Curriculum contents: origin and consolidation of the } \\
\text { nation }\end{array}$ & & & & & & 0.441 & -0.535 & & & & \\
\hline $\begin{array}{l}\text { The historian's methods are fundamental in education } \\
\text { curricula }\end{array}$ & & 0.477 & & & & -0.421 & & & & & \\
\hline Reading skills and memorizing are enough & & & & & & & & & & & 0.582 \\
\hline It is complicated to use enquiry methods & & & & 0.345 & & & -0.589 & & -0.315 & & \\
\hline $\begin{array}{l}\text { New technologies help to enhance historical knowledge } \\
\text { through interactivity }\end{array}$ & & & 0.420 & & & 0.581 & & & & & \\
\hline $\begin{array}{l}\text { New technologies only help to enhance historical } \\
\text { knowledge with access to working with sources }\end{array}$ & & & & & & & & & -0.669 & & \\
\hline Understanding the present & & & & & & & & 0.684 & & & \\
\hline Knowing the origin and consolidation of the nation & & & & 0.752 & & & & & & & \\
\hline Educating in social and civic values & & & & & & & & 0.681 & & & \\
\hline $\begin{array}{l}\text { Knowing the methods for reconstructing and explaining } \\
\text { historical events }\end{array}$ & & 0.395 & & & 0.698 & & & & & & \\
\hline $\begin{array}{l}\text { Developing educational competences in vocabulary, } \\
\text { chronology, etc. }\end{array}$ & & & & & 0.803 & & & & & & \\
\hline Textbook & & & & & & & & & 0.655 & & \\
\hline Internet & 0.442 & & & & & & & & & -0.324 & 0.383 \\
\hline Documentary resources & & 0.342 & & & & & 0.416 & -0.469 & & & \\
\hline Oral sources & & 0.472 & & & & & & & & 0.533 & \\
\hline Press & 0.583 & & & & & & & & -0.349 & & \\
\hline Teachers' notes & & & & & & & & & & 0.758 & \\
\hline Museums and other centers of historical interest & 0.437 & & & & & 0.352 & & & & 0.407 & \\
\hline Cinema & 0.638 & & 0.430 & & & & & & & & \\
\hline Documentaries & 0.752 & & & & & & & & & & \\
\hline Historical novels & 0.704 & & & & & & & & & & \\
\hline Popular magazines & 0.751 & & & & & & & & & & \\
\hline Videogames & & & 0.812 & & & & & & & & \\
\hline Comics & & & 0.783 & & & & & & & & \\
\hline Traditional local fiestas & & 0.421 & & -0.437 & & & & & & & \\
\hline Teachers' explanations & & & & 0.600 & & & & & & 0.312 & \\
\hline History simulation strategies & .314 & & & 0.423 & & 0.355 & & & & & \\
\hline Using key topics of current interest & & 0.488 & & & & & & 0.373 & & & \\
\hline Problem solving & & 0.750 & & & & & & & & & \\
\hline In-depth studies of historical cases & & 0.768 & & & & & & & & & \\
\hline Outings to centers of historical interest & 0.408 & 0.346 & & & 0.422 & & & & & & \\
\hline Guided debates & 0.541 & 0.343 & & & & & & 0.304 & & & \\
\hline
\end{tabular}


The first component shows the interactions between the evaluation of the usefulness of the following resources in teaching history: Internet, press, museums, popular magazines, historical cinema, documentaries, and historical novels - with the following methodological strategies: simulation strategies and empathy, debates on historical issues, and outings to centers of historical interest. In the second component extracted the interrelations between the item that indicates that it is necessary to incorporate the historian's method into the classroom with the item that states that the purpose of history as a formative subject, is to know the methods to construct the past. These items saturate with positive loads with documentary and oral sources, the use of local fiestas and traditions, and with all methodological inquiry strategies except historical simulation. The third component extracted shows the interaction between the item that states that the use of new technologies helps learning with the following resources: historical cinema, video games, and comics. In the fourth component extracted, the interactions between the item stating that it is complicated to use investigation methods in the history classroom, the item that indicates that the purpose of the teaching of history is to know the origins of the nation, and the valuation of the explanation of the professor as a methodological strategy can be verified. This component saturates with negative loads with the item that history is a subjective interpretation of the historian and the use of local fiestas and traditions as a resource for teaching history. The fifth component extracted shows the relationships between the assessment of the items on the purpose of history as a means of knowing the methods of reconstructing the past and the purpose based on educational skills with the positive scores for guided debates in the classroom.

The sixth component extracted shows a saturation with positive charges between the item that indicates that disagreement among historians comes from problems with the source; the item that affirms that the contents of the curriculum should be based on the main milestones of nation building, the positive valuation of the use of museums as an educational resource, and historical simulations as a methodological strategy. In this component there are negative loads with the item that states that including the historian's method in curricula is fundamental. The seventh component extracted shows interactions between the item that affirms that history is a critical investigation of the past and the positive evaluation of the use of documentary sources as a resource. In this component they saturate with negative loads the item that affirms that the contents are based on the main milestones of the nation, and against the fact that ICTs improve learning through their interactivity. The eighth component extracted shows positive loads between the item indicating that the purpose of history is to know the present and learn civic values, with the positive assessment of using current key issues of interest and guided debates as methodological strategies. In this component they saturate the assessment of the use of documentary sources with negative burdens. In the ninth component extracted, negative loads are shown between the use of the press as a teaching resource, the item that states that inquiry strategies are complicated, and that ICTs only help when primary sources are used. In this component there are positive loads with the use of the textbook as a resource. In the tenth component extracted there are interrelations between the assessment of oral sources, the use of teachers' notes, the use of museums, and the explanation of the teacher as a methodological strategy. On the other hand, there are negative loads for the use of the Internet as a resource. The eleventh component extracted shows relationships between the item which states that history is basically knowledge of the past, the item which indicates that disagreements between historians are due to a subjective interpretation by the historian, and the item which states that good reading skills allow interpretation of historical sources.

\section{Discussion and Conclusions}

The first objective of this work was to compare the assessment of Spanish and English trainee teachers on the role of cultural heritage in the teaching-learning process. The common starting points of the answers in the comparison between countries are a positive evaluation of the active learning methodologies, working with sources, and the development of historical competences. This assessment seems to be the result of the effort carried out in recent decades by research and innovation groups in 
historical education at an international level, which have advocated surpassing teaching methodologies based on linear and factual content in favor of teaching critical history and providing civic values.

Spanish and English trainee teachers agree that the history forged by elites and patriots does not serve in a multicultural and global context, which is in line with research in recent years. To counter the uncritical memorization of the past, they opt for resources, methodological strategies, and evaluation procedures that develop historical thinking among students through historical sources and critical reasoning [76], that is, through the historians' method, due to their ability to question a historical source, contextualize it, and seek answers to the key to history as a discipline [77]. Indeed, the use of heritage to work on historical sources and evidence is one of the main lines of research in heritage education [78]. This allows students to express how they understand the past from the inferences they make from sources and to become aware of their orientation in historical time. Working with sources opens the doors to new ways of using heritage material from an educational perspective, and so contributes to the development of historical awareness and equity, with a focus on classroom activities [79].

Therefore, heritage can play a decisive role in this sense, and this is the perception of the trainee teachers in Spain and England from their answers to the questionnaire, albeit with some nuances. Future Spanish teachers give a high or very high score to heritage as a teaching resource in the history classroom. The English trainee teachers' responses were more moderate; despite scoring heritage as a resource moderate to high, they gave more importance to the use of primary sources and to solving historical problems through the search and selection of historical sources and evidence. It is not surprising that the English teachers surveyed gave greater relevance to the use of primary sources for the teaching of history than the Spanish, since the teaching traditions are different, with a more methodological and procedural view of history in England, where the impact of research projects such as Concept History and Teaching Approaches (CHATA) or the changes introduced by the 1991 National Curriculum are highly evident. But it is striking that these questions are not more closely linked to the potential of heritage to carry them out, as occurs in Spain. On the one hand, the great bibliographic vitality and, on the other, the commitment of the Central Administration with a National Plan and an Observatory, and later some regions such as Murcia or Madrid with their own educational plans, mean that the development of heritage education in Spain is partly responsible in this assessment [9]. The important weight of history of art in the curriculum and Spanish textbooks, compared to English ones, are also plausible explanations [80]. In both countries, the vision of local history and intangible heritage continues to have a more modest value.

The second objective of this study focuses on delimiting the existing connections between previous conceptions of history as a formative subject and valuations of the role of cultural heritage in teaching-learning processes. In this sense, very clear links are identified in Spain between epistemological and innovative methodological conceptions of history and the use of local museums and festivals as a teaching resource, as well as excursions to places of historical interest as a methodological strategy. This is in line with a recent, fast-developing vision which is strongly influenced by international texts in the context of the European Union, such as the Faro Convention, which call for the value of the heritage experience $[4,81]$, as well as the necessary participation and management of people and communities not only in learning but in the actual selection and use of cultural heritage [82]. They also converge with studies that reinforce the need to incorporate the non-formal spheres-fundamentally museums and heritage sites-in the curriculum in areas related to the social sciences, going as far as to consider museums as essential contexts for transforming experiences and the development of identity $[83,84]$.

In contrast to this more contemporary approach, there persists a more conservative vision: there are several main components that unite the positive evaluation of textbooks, the teacher's notes, or the teacher's explanation, with he underlying, more static conception that sees simple reading skills as sufficient to interpret historical sources [85]. This contrasts with approaches derived from recent studies, which advocate performative, even communitarian, techniques for teaching historical heritage 
in England [86]. While the links are more diffuse in England, in Spain the vision that considers that the historian's method should be introduced into the classroom tends to be linked to items on heritage and active learning methods. Trainee teachers in England seem to be clear that the purpose of teaching history should be based on the replica of the historian's methods, but they do not score resources, strategies, or techniques that have a motivational component such as ICT, comics, outings, videogames, etc. as highly as the Spaniards [87]. In England, unlike Spain, there are no such close links between the teaching of history and the emotional or motivational dimension. This places us among more historicist models-in the case of England-and identitarian [88] or experiential symbolic approaches-in the case of Spain-which place the training of future teachers nearer to a more holistic vision of heritage education [89], close to the idea of transcomplexity [90]. It is understood that it is knowledge as a historian-derived from his initial training - that allows him to identify and understand the sources, but it is his training as a teacher-derived from the master's program itself-that gives him strategies for projecting values, establishing links, and, in short, shaping identity references in the learners.

\section{Educational Implications}

The educative implications of this research must start in the initial training of teachers. Curricula must include subjects or, at least, content blocks related to the teaching of historical heritage [91]. This could allow them to take into classrooms procedures to improve the use of historical heritage in the classroom [92]. The research results show that this improvement should be based on epistemological and methodological precepts. On the methodological precepts, the use of heritage in the classroom should be based on active methodologies, centered on students, and on their previous experiences with historical and cultural heritage. On the epistemological precepts, we must overcome this vision of heritage related with a monumental and descriptive point of view. Teachers in training must learn to use historical and cultural heritage as a historical source. Through this source students can develop skills in extracting information from the past and in interpreting history. Many authors have indicated the necessity of improving the teaching practice in teacher education to train highly qualified teachers. This is an issue of current interest on an international level [93-96]. More comparative research is necessary, as empirical studies in higher education need to have systematic contact with the subsequent results [97]. Studies in other contexts in Higher Education have shown how active teaching strategies improve student motivation and competencies [98-102].

Secondly, normative proposals regarding educational laws and curricula should increase the presence of heritage in legal texts and norms [103]. In addition, the conception that the curriculum gives to heritage is key, insofar as it can favor or hinder the introduction of heritage in teaching, since it guides the elaboration of materials, the curricular project of the center, the contents of textbooks, and influences teachers' training [104].

The next area to address is the educational center, which has to include the treatment of heritage in the educational project and in the didactic programs through programs of outings, through which students approach the historical past of their own community, connecting with their nearest reality [82]. It is here that information acquires its meaning, with in situ experience being the context in which learning would take place and where attitudes of valuing and preserving the cultural plurality that surrounds the students would be developed [32].

The study of a historical event is the perfect occasion to reinforce students' abilities and attitudes and to develop the mastery of techniques and instruments. In order to improve historical education, it is necessary for teachers to use alternative methodologies, but also to change the epistemological burdens that conceive history as a set of closed knowledge, and to use the development of historical thinking through key resources such as heritage. Inquiring into the training of those who will be teachers in the future can reveal what needs to be modified.

In the classroom, heritage has to be one more source for teachers, who should adopt an active role and a critical perspective in order to connect the classroom and the environment, relating activities and outings with programming and active methods such as problem-based learning, which involve 
students in solving problems posed, whether current or past, thus enhancing motivation and interest in the subject by making it more useful and functional [20].

The current university curricula need to focus on training that will enable future secondary school teachers to implement these strategies. One of the most important facets is to learn to use historical sources, including heritage, didactically [49].

The process that unites heritage elements with the promotion of historical thinking requires a change in didactic methodology: moving from master classes to inquiry methods, active learning methods, and the use of a variety of resources [71]. Methodologically, problem-based learning is very useful compared to traditional expository approaches [105]. Through work based on problem solving, it is possible to establish synthetic discourses that facilitate the ordering and structuring of historical information. Simulation or debates on real situations foster this systemic relationship of historical knowledge, while mobilizing attitudes and modes of operation. Similarly, case studies $[106,107]$ and the incorporation of the study of reality and social phenomena are an innovative way of bringing historical knowledge closer to the students, and also allow a greater application of these contents in the understanding and analysis of society, while enabling students to conceive them beyond closed, impractical knowledge. Teachers should encourage debates, sharing, discussions, and studies so that students can know and participate in their school community [108].

Finally, this also means continuing to make heritage teaching an emerging field of research that is consolidated within the didactics of history, and all of this within the premises of historical education, the construction of a critical citizenship, and identity education [10].

Supplementary Materials: The following are available online at http:/www.mdpi.com/2071-1050/12/3/933/s1.

Author Contributions: Conceptualization, C.J.G.-C., O.F., and A.I.-E.; methodology, C.J.G.-C. and P.M.-M.; software, C.J.G.-C. and P.M.-M.; validation, C.J.G.-C., O.F., and P.M.-M.; formal analysis, C.J.G.-C. and A.I.-E.; investigation, C.J.G.-C. and A.I.-E.; data curation, C.J.G.-C.; writing-original draft preparation, C.J.G.-C. and A.I.-E.; writing-review and editing, O.F. and P.M.-M.; project administration, C.J.G.-C.; funding acquisition, C.J.G.-C., P.M.-M., O.F., and A.I.-E. All authors have read and agreed to the published version of the manuscript.

Funding: This research was funded by the Sànish Ministerio de Ciencia, Universidades e Innovación de España (MINECO/FEDER) under projects EDU2015-65716-C2-1-R, EDU2015-65716-C2-2-R, and PGC2018-094491-B-C33 and by the Fundación Séneca de la Región de Murcia under projects 20638/JLI/18 and 20874/PI/18.

Acknowledgments: We thank Arthur Chapman for helping us to contact England universities. Also we thank to the coordinators, teachers, and students from the Universities of Murcia, Alicante, Valencia, Barcelona, La Rioja, Zaragoza, Oviedo, Santander, Valladolid, Burgos, Autónoma de Madrid, Málaga, Jaén, IoE-UCL, Exeter, Edge Hill, Metropolitan Manchester, York, Leeds, East-Anglia, Birmingham, and Christ Church of Cantebury who took part in this research for their collaboration.

Conflicts of Interest: The authors declare no conflict of interest.

\section{References}

1. Corredor, J.; Emma, M.; Asensio, M. Historical memory education for peace and justice: Definition of a field. J. Peace Educ. 2018, 15, 169-190. [CrossRef]

2. Cuenca, J.M.; Martín, M.; Schugurensky, D. Citizenship education and identity in U.S. museums: An analysis from a heritage education perspective. Estudios Pedagógicos. 2017, 43, 29-48. [CrossRef]

3. Gosselin, V.; Livingstone, P. Museums and the Past. Constructing Historical Counsciousness; UBC Press: Vancouver, BC, Canada, 2016.

4. Jagielska-Burduk, A.; Piotr, S. Council of Europe Culture Heritage and Education Policy: Preserving Identity and Searching for a Common Core? Revista Electrónica Interuniversitaria de Formación del Profesorado 2019, 22, 1-2. [CrossRef]

5. Sivan, A.; Tam, V.; Siu, G.; Stebbins, R. Adolescents' choice and pursuit of their most important and interesting leisure activities. Leisure Stud. 2019, 38, 98-113. [CrossRef]

6. Van Boxtel, C.; Grever, M.; Klein, S. Heritage as a Resource for Enhancing and Assessing Historical Thinking: Reflections from the Netherlands. In New Directions in Assessing Historical Thinking; Ercikan, K., Seixas, P., Eds.; Routledge: Abingdon on Thames, UK, 2015. 
7. Domingo, M.; Fontal, O.; Ballesteros, P. Plan Nacional de Educación y Patrimonio; Ministry of Education, Culture and Sport: Madrid, Spain, 2016.

8. Fontal, O. The Spanish Heritage Education Observatory. Cult. Educ. 2016, 8, 254-266. [CrossRef]

9. Fontal, O.; Ibañez-Etxeberria, A. Research on Heritage Education. Evolution and Current State Through Anlysis of High Impact Indicators. Revista de Educación 2017, 375, 184-214.

10. Monteagudo, J.; López-Facal, R. Standards of learning and assessment historical thought: Incompatible? Analysis of curricula, programming, exams and expert opinions in Spain. Perfiles Educativos 2018, 40, 128-146. [CrossRef]

11. Fontal, O.; Gómez-Redondo, C. Heritage Education and Heritagization Processes: SHEO Methodology for Educational Programs Evaluation. Interchange 2016, 47, 65-90. [CrossRef]

12. Fontal, O.; Ibañez-Etxeberria, A. Strategies and tools for Heritage Education in Spain. Educatio Siglo XXI 2015, 33, 15-32.

13. Martín, M.J.; Cuenca, J.M. Heritage Education and Learning in Museums: The Managers' Perspective. J. Psychodidactics 2011, 16, 99-122.

14. Vicent, N.; Ibañez-Etxeberria, A.; Asensio, M. Evaluation of heritage education technology-based programs. Virtual Archaeol. Rev. 2015, 13, 18-25.

15. Ibañez-Etxeberria, A.; Gillate, I.; Madariaga, J.M. The use of the oral history as a resource to learn historical contents in Secondary Education and its relation with the local identity, motivation and social selfconcept. Tempo e Argumento 2015, 7, 204-229. [CrossRef]

16. Ibañez-Etxeberria, A.; Vicent, N.; Asensio, M.; Cuenca, J.M.; Fontal, O. Learning in archaeological sites with mobile devices. Munibe 2014, 65, 313-321.

17. Suárez, M.Á.; Calaf, R.; Fernández Rubio, M.C. The communication of heritage: Assessment of the communicative process in museums of Asturias. Fonseca J. Commun. 2017, 14, 131-146. [CrossRef]

18. Calaf, R.; San Fabián, J.L.; Gutiérrez Berciano, S. Evaluating educational programs in museums: A new perspective. Bordon Revista de Pedagogía 2017, 69, 45-65. [CrossRef]

19. Martínez-Gil, T.; López-Benito, V.; Asensio, M.; Santacana, J. Entertainment or learning? Mobile technologies evaluation for heritage education. Ensayos 2018, 33, 39-52.

20. Cuenca, J.M.; López, I. Teaching heritage in Social Science, Geography and History textbooks in Compulsory Secondary Education. Cult. Edu. 2014, 26, 1-43. [CrossRef]

21. Asensio, M. Natural learning, the best way to approach the heritage. Educatio Siglo XXI 2015, 33, 55-82. [CrossRef]

22. Fontal, O.; García-Ceballos, S.; Arias, B.; Arias, V. Assessing the quality of heritage education programs: Construction and calibration of the Q-Edutage scale. J. Psychodidactics 2019, 24, 31-38. [CrossRef]

23. Lorca, A.A.; Cuenca, J.M.; Vázquez, B. Survey on attitudes and concepts in videogames and teaching involvement in the science classroom (CVJ/AC): Psychometric properties. IJERI Int. J. Educ. Res. Innov. 2018, 11, 101-120.

24. Gómez-Redondo, C.; Calaf, R.; Fontal, O. Design of an instrument of analysis for heritage educational resources. Cadmo 2017, 25, 63-80. [CrossRef]

25. Suárez, M.A.; Calaf, R.; San Fabián, J.L. Learning history through heritage. Two case studies: The Railway Museum of Asturias and the Immigration Museum of Catalonia. Revista de Educación 2014, 365, 38-66. [CrossRef]

26. Fontal, O.; Marín-Cepeda, S. Inclusive heritage: Towards an index for the evaluation of educational inclusion to heritage. CADMO 2018, 18, 7-24. [CrossRef]

27. Marín-Cepeda, S.; García-Ceballos, S.; Vicent, N.; Gillate, I.; Gómez-Redondo, C. Inclusive Heritage education in SHEO: A prospective study. Revista de Educación 2017, 375, 110-135. [CrossRef]

28. Pablos, L.; Fontal, O. Evaluation of heritage education programs in museums for people with ASD. RIDE Revista Iberoamericana para la Investigación y el Desarrollo Educativo 2019, 9, 234-253. [CrossRef]

29. Pablos, L.; Fontal, O. Inclusive programs for people with Autistic Spectrum Disorder (ASD) in museums. Examples of good practise. Revista Iberoamericana de Educacion 2018, 76, 23-38.

30. Fontal, O.; Marín-Cepeda, S. Heritage Education in Museums: An Inclusion-Focused Model Secondary document. Int. J. Incl. Mus. 2016, 9, 47-64. 
31. Cuenca, J.M.; Molina, S.; Martín, M. Identity, citizenship and heritage. Comparative analysis of education treatment in museums in the United States of America and Spain. Arbor. Revista de Ciencia Pensamiento y Cultura 2018, 18, a447.

32. Domínguez Almansa, A.; López Facal, R. Conflictive heritages, civic competence and professional training in primary education. Revista de Educación 2017, 375, 86-109.

33. Cuenca López, J.M.; Giménez, J.E.; Martín Cáceres, M.J. El Patrimonio Cultural en la Educación Reglada; Patrimonio Cultural de España: Madrid, Spain, 2011.

34. Bardavio, A.; González Marcén, P. Objetos en el Tiempo: Las Fuentes Materiales en la Enseñanza de Las Ciencias Sociales; ICE Universitat de Barcelona: Barcelona, Spain, 2003.

35. Corbishley, M. Pinning Down the Past: Archaeology, Heritage, and Education Today; Boydell and Brewer: Woodbridge, UK, 2011.

36. Larouche, M.-C. Using museums resources and mobile technologies to develop teens' historical thinking formative evaluation of an innovative educational set-up. In Museums and the Past. Constructing Historical Counsciousness; Gosselin, V., Livingstone, P., Eds.; UBC Press: Vancouver, BC, Canada, 2016.

37. Levstik, L.; Henderson, A.G.; Schlarb, J.S. Digging for clues: An archaeological exploration of historical cognition. In Researching History Education. Theory, Method, and Context; Levstik, L., Barton, K., Eds.; Routledge: Abingdon on Thames, UK, 2008.

38. Philips, I. Highlighting evidence. In Debates in History Teaching; Davies, I., Ed.; Routledge: Abingdon on Thames, UK, 2011.

39. Saiz-Serrano, J.; Gómez-Carrasco, C.J.; López-Facal, R. National Narratives and Historical Competencies in Spanish Initial Teacher Training. Tempo e Argumento 2017, 9, 174-197. [CrossRef]

40. Seixas, P.; Morton, T. The Big Six Historical Thinking Concepts; Nelson Education: Toronto, ON, Canada, 2013.

41. Gómez, C.J.; Miralles, P. Thinking Historically or Memorizing the Past? Assessing Historical Content in Compulsory Education in Spain. Revista de Estudios Sociales 2015, 52, 52-58. [CrossRef]

42. Lévesque, S. Le pensée historique: Pour le développement de le litératie critique en histoire. In Canadian Issues/Thèmes Canadiens; ProQuest Information and Learning Company: Ann Arbor, MI, USA, 2011; pp. $13-16$.

43. Seixas, P. Historical Counsciousness and Historical Thinking. In Palgrave Handbook of Research in Historical Culture and Education; Carretero, M., Grever, M., Berger, S., Eds.; Palgrave McMillan: London, UK, 2017.

44. VanSledright, B.A. Assessing Historical Thinking y Understanding. Innovate Designs for New Standards; Routledge: Abingdon, UK, 2014.

45. Wineburg, S. Historical Thinking and Other Unnaturals Acts: Charting the Future of Teaching the Past; Temple University Press: Philadelphia, PA, USA, 2001.

46. De Groot, J. Consuming History: Historians and Heritage in Contemporary Popular Culture; Routledge: New York, NY, USA, 2008.

47. Domínguez-Almansa, A.; López-Facal, R. Teacher training and Heritage education. Estudios Pedagógicos 2017, 43, 49-68.

48. Éthier, M.; Demers, S.; Lefrançois, D. Las investigaciones en didáctica sobre el desarrollo del pensamiento histórico en la enseñanza primaria. Una panorámica de la literatura publicada en francés e inglés desde el año 1990. Enseñanza de las Ciencias Sociales. Revista de Investigación 2010, 9, 61-74.

49. Gómez, C.J.; Miralles, P. Los Espejos de Clío. Usos y Abusos de la Historia en el ámbito Escolar; Sílex: Madrid, Spain, 2017.

50. Ashby, R. Understanding historical evidence. Teaching and learning challenges. In Debates in History Teaching; Davies, I., Ed.; Routledge: Abingdon on Thames, UK, 2011.

51. Domínguez, J. Pensamiento Histórico y Evaluación de Competencias; Graó: Barcelona, Spain, 2015.

52. González, G.; Skultety, L. Teacher learning in a combined professional development intervention. Teach. Teacher Educ. 2018, 71, 341-354. [CrossRef]

53. Barnes, N.; Fives, H.; Dacey, C. U.S. teachers' conceptions of the purposes of assessment. Teach. Teacher Educ. 2017, 65, 107-116. [CrossRef]

54. König, J.; Blömeke, S. Future teachers' general pedagogical knowledge from a comparative perspective: Does school experience matter? ZDM 2012, 44, 341-354. [CrossRef]

55. KÖniga, J.; Ligtvoeta, R.; Klemenza, S.; Rothlandb, M. Effects of opportunities to learn in teacher preparation on future teachers' general pedagogical knowledge: Analyzing program characteristics and outcomes. Stud. Educ. Eval. 2017, 53, 122-133. [CrossRef] 
56. Fives, H.; Buehl, M.M. Exploring differences in practicing teachers' valuing of pedagogical knowledge based on teaching ability beliefs. J. Teacher Educ. 2014, 65, 435-448. [CrossRef]

57. Virta, A. Becoming a history teacher: Observations on the beliefs and growth of student teachers. Teach. Teacher Educ. 2002, 18, 687-698. [CrossRef]

58. König, J.; Pflanzi, B. Is teacher knowledge associated with performance? On the relationship between teachers' general pedagogical knowledge and instructional quality. Eur. J. Teacher Educ. 2016, 39, 1-18. [CrossRef]

59. Oliveira, C.; Lopez, J.; Spear-Swerling, L. Teachers' academic training for literacy instruction. Eur. J. Teacher Educ. 2019, 43, 315-334. [CrossRef]

60. Pollock, S.A. The Poverty asn Possibility of Historical Thinking: An Overbiew of Recent Research into History Teacher Education. In Becoming a History Teacher; Sandwell, R., Heyking, A.V., Eds.; University of Toronto Press: Toronto, ON, Canada, 2014.

61. Stoel, G.; Logtenbergb, A.; Wansinkc, B.; Huijgend, T.; Van Boxtel, C.; Van Drie, J. Measuring epistemological beliefs in history education: An exploration of naïve and nuanced beliefs. Int. J. Educ. Res. 2017, 83, 120-134. [CrossRef]

62. Van Straaten, D.; Wilschut, A.; Oostdam, R. Measuring students' appraisals of the relevance of history: The construction and validation of the Relevance of History Measurement Scale (RHMS). Stud. Educ. Eval. 2018, 56, 102-111. [CrossRef]

63. De Groot-Reuvekamp, M.; Anje, R.; Van Boxtel, C. 'Everything was black and white': Primary school pupils' naive reasoning while situating historical phenomena in time. Education 2019, 47, 1-16. [CrossRef]

64. De Groot-Reuvekamp, M.; Ros, A.; Van Boxtel, C. A successful profesional development program in history: What matters? Teach. Teacher Educ. 2018, 75, 290-301. [CrossRef]

65. Hernández, F.; Maquilón, J.J. Introducción a los diseños de investigación educativa. In Principios, Métodos Técnicas Esenciales Para la Investigación Educative; Nieto, S., Ed.; Dykinson: Madrid, Spain, 2010.

66. Sapsford, R.; Jupp, V. Data Collection and Analysis; Sage: London, UK, 2006.

67. Maggioni, L.; VanSledright, B.; Alexander, P.A. Walking on the borders: A measure of epistemic cognition in history. J. Exp. Educ. 2009, 77, 187-214. [CrossRef]

68. VanSledright, B.A.; Reddy, K. Changing Epistemic Beliefs? An Exploratory Study of Cognition Among Prospective History Teacher. Tempo e Argumento 2014, 6, 28-68. [CrossRef]

69. Stoel, G.L.; Van Drie, J.P.; Van Boxtel, C.A. The effects of explicit teaching of strategies, second-order concepts, and epistemological underpinnings on students' ability to reason causally in history. J. Educ. Psychol. 2016, 109, 321-337. [CrossRef]

70. Gómez, C.J.; Miralles, P.; Chapman, A. The assessment procedures when teaching history. A comparative analysis through the opinions of teachers in training in Spain and England. Revista Electrónica Interuniversitaria de Formación del Profesorado 2017, 20, 45-61.

71. Gómez, C.J.; Rodríguez, R.A.; Mirete, A.B. Perception of teaching history and epistemological conceptions. Research with future teachers. Revista Complutense de Educación 2018, 29, 237-250.

72. Gestsdóttir, S.M.; Van Boxtel, C.; Van Drie, J. Teaching historical thinking and reasoning: Construction of an observation instrument. Br. Educ. Res. J. 2018, 44, 960-981. [CrossRef]

73. González, J.; Pazmiño, M. Calculation and interpretation of Cronbach's Alpha for the validation of the internal consistency of a questionnaire, with two possible Likert scales. Revista Publicando 2015, 2, 62-77.

74. Oviedo, H.C.; Campo-Arias, A. An Approach to the Use of Cronbach's Alfa. Rev. Colomb. Psiquiatr. 2005, 34, 572-580.

75. Lloret-Segura, S.; Ferreres-Traver, A.; Hernández-Baeza, A.; Tomás-Marco, I. Exploratory Item Factor Analysis: A practical guide revised and up-dated. Ann. Psychol. 2014, 30, 1151-1169.

76. Lévesque, S.; Zanazanian, P. History Is a Verb: "We Learn It Best When We Are Doing It!": French and English Canadian Prospective Teachers and History. Revista de Estudios Sociales 2015, 52, 32-51. [CrossRef]

77. Prats, J. Combates por la historia en educación. Enseñanza de las Ciencias Sociales Revista de Investigación 2016, 15, 145-153.

78. Pinto, H. Using heritage in history education: Portuguese students and teachers' perspectives concerning identity and historical conciousness. Educatio Siglo XXI 2013, 31, 61-88.

79. Miralles, P.; Alfageme, M.B. Educación, identidad y ciudadanía en un mundo globalizado y posmoderno. Educatio Siglo XXI 2013, 31, 11-24. 
80. Gómez, C.J.; Chapman, A. Historiographical approaches and social representations in textbooks. A comparative study, Spain-France-England. Historia y Memoria de la Educación 2017, 6, 319-361.

81. Kim, Y.G. Developments of Cultural Heritage Education and the Raising of Local Cultural Heritage Education. Ann. Rev. Cult. Prop. Stud. 2018, 51, 154-169.

82. McGill, A.E. Examining the Pedagogy of Community-Based Heritage Work through an International Public History Field Experience. Public Hist. 2018, 40, 54-83. [CrossRef]

83. Rivero, P.; Fontal, O.; García-Ceballos, S.; Martínez, M. Heritage Education in The Archaeological Sites. An Identity Approach in The Museum of Calatayud. Curator Mus. J. 2018, 61, 315-326. [CrossRef]

84. Garner, J.K.; Kaplan, A.; Pugh, K. Museums as contexts for transformative experiences and identity development. J. Mus. Educ. 2016, 41, 341-352. [CrossRef]

85. Alves, L.A.; Pinto, H. History education through heritage: Challenging teacher training. Revista Electrónica Interuniversitaria de Formacion del Profesorado 2019, 22, 71-81.

86. Bartie, A.; Fleming, L.; Freeman, M.; Hulme, T.; Hutton, A.; Readman, P. 'History taught in the pageant way': Education and historical performance in twentieth-century Britain. Hist. Educ. 2018, 48, 1-24. [CrossRef]

87. Miralles, P.; Gómez-Carrasco, C.J.; Monteagudo, J. Perceptions on the use of ICT resources and «mass-media» for the teaching of history. A comparative study among future teachers of Spain-England. Educación XXI 2019, 22, 187-211. [CrossRef]

88. Fontal, O. La Educación Patrimonial. Teoría y Práctica en el aula, el Museo e Internet; Trea: Gijón, Spain, 2003.

89. Cuenca, J.M. El Patrimonio en la Didáctica de las Ciencias Sociales. Análisis de Concepciones, Dificultades y Obstáculos Para su Integración en la Enseñanza Obligatoria; University of Huelva: Huelva, Spain, 2002.

90. Rodríguez, M.E. Heritage education and teacher education from the Transcomplejidad/La Educación Patrimonial y la Formación Docente desde la Transcomplejidad. Revista Telos 2018, 20, 431-450.

91. Fontal, O. Heritage through Arts Education in Primary Stage. Arte Individuo y Sociedad 2016, 18, $105-120$.

92. Fontal, O.; Ibañez-Etxeberria, A.; Martínez, M. Heritage as Content in Primary Education: From the Curriculum to Teacher Education. REIFOP 2017, 20, 79-95.

93. Cochran-Smith, M.; Zeichner, K.M. Studying Teacher Education: The Report of the AERA Panel on Research and Teacher Education; Routledge: Abingdon on Thames, UK, 2005.

94. Darling-Hammond, L.; Bransford, J.D. Preparing Teachers for a Changing World: What Teachers Should Learn and be Able to Do; Jossey-Bass: San Francisco, CA, USA, 2005.

95. KÖnig, J.; Ligtvoet, R.; Klemenz, S.; Rothland, M. Efectos de las Oportunidades de Aprender en la Preparación del Profesorado Sobre el Conocimiento Pedagógico general de los Futuros Maestros: Análisis de las Características y Resultados del Programa; Elsevier: Amsterdam, The Netherlands, 2017; pp. 122-133.

96. Floden, R. Learning what research says about teacher preparation. In Past as Prologue: The National Academy of Education at 50. Members Reflect; Feuer, M.J., Berman, A.I., Atkinson, R.C., Eds.; National Academy of Education: Washington, DC, USA, 2015.

97. BlÖmeke, S.; Suhl, U.; Kaiser, G.; DÖhrmann, M. Family background, entry selectivity and opportunities to learn: What matters in primary teacher education? An international comparison of fifteen countries. Teach. Teacher Educ. 2012, 28, 44-55. [CrossRef]

98. Chen, H.Y.L.; Chen, N.S. Design and evaluation of a flipped course adopting the holistic flipped classroom approach. In Proceedings of the IEEE 14th International Conference on Advanced Learning Technologies, Athens, Greece, 7-10 July 2014.

99. O'Flaherty, J.; Phillips, C. The use of flipped classrooms in higher education: A scoping review. Intern. Higher Educ. 2015, 25, 85-95. [CrossRef]

100. Velegol, S.B.; Zappe, S.E.; Mahoney, E.M.I.L.Y. The Evolution of a Flipped Classroom: Evidence-Based Recommendations. Adv. Eng. Educ. 2015, 4, 1-37.

101. Young, T.P.; Bailey, C.J.; Guptill, M.; Thorp, A.W.; Thomas, T.L. The flipped classroom: A modality for mixed asynchronous and synchronous learning in a residency program. West. J. Emerg. Med. 2014, 15, 938-944. [CrossRef]

102. Findlay-Thompson, S.; Mombourquette, P. Evaluation of a flipped classroom in an undergraduate business course. Bus. Educ. Accredit. 2014, 6, 63-71.

103. Cuenca López, J.M. Heritage in the school: To Heritage socialization. Tejuelo 2014, 19, 76-96. 
104. González, N.; Pagés, J. La presencia del patrimonio en los currículos de historia y ciencias sociales en la enseñanza obligatoria. In El Patrimonio y la didáctica de las Ciencias Sociales; Ballesteros, E., Ed.; AUPDCCSS-UCLM: Cuenca, Ecuador, 2003; pp. 123-133.

105. Oller, M. Métodos y estrategias para la enseñanza y el aprendizaje de las Ciencias Sociales. In Didáctica del Conocimiento del Medio Social y Cultural en la Educación Primaria; Santisteban, A., Pagès, J., Eds.; Síntesis: Madrid, Spain, 2011; pp. 163-183.

106. Gil, P.; Ibañez-Etxeberria, A. Perception of usefulness and satisfaction levels of education students with the Case Method. Aula Abierta 2013, 41, 79-90.

107. Prats, J. Estudios de caso único como método para el aprendizaje de los conceptos históricos y sociales. Cuadernos Digitales. Recuperado de. Available online: http://www.quadernsdigitals.net/datos_web/ hemeroteca/r_1/nr_609/a_8304/8304.html (accessed on 25 January 2020).

108. Gómez, C.J.; Ortuño, J.; Miralles, S. Enseñar Ciencia Sociales desde métodos Activos. Propuestas y Experiencias desde la Indagación; Octaedro: Barcelona, Spain, 2018.

(C) 2020 by the authors. Licensee MDPI, Basel, Switzerland. This article is an open access article distributed under the terms and conditions of the Creative Commons Attribution (CC BY) license (http://creativecommons.org/licenses/by/4.0/). 